\title{
TRANSCORTIN : A CORTICOSTEROID-BINDING PROTEIN OF PLASMA. II. LEVELS IN VARIOUS CONDITIONS AND THE EFFECTS OF ESTROGENS *
}

\author{
By AVERY A. SANDBERG AND W. ROY SLAUNWHITE, JR. \\ (From the Departments of Medicine and Biochemistry Research, Roswell Park Memorial \\ Institute, Buffalo, N. Y.)
}

(Submitted for publication February 2, 1959; accepted April 2, 1959)

Evidence for the existence in human plasma of a protein with high affinity for the binding of corticosteroids, which we have named transcortin, has been recently published from several laboratories (1-5). Even though the concentration of transcortin is considerably lower than that of albumin, the former binds cortisol approximately 6,000 times as strongly as does the latter (5). Therefore, under physiological conditions most of the plasma cortisol has been shown to be bound to transcortin. Transcortin appears to be saturated at plasma levels of cortisol of approximately 30 to $40 \mu \mathrm{g}$. per cent (4-5). Some of the characteristics of the corticosteroid-binding protein have been described by Daughaday $(2,6)$, Bush (3), Upton and Bondy (4) and ourselves (5).

In a previous paper we reported a method for measuring the binding capacity of transcortin in plasma and showed it to be increased in the plasma of pregnant women (5). Since the concentration of transcortin may play an important role in the metabolism and biological effects of cortisol, it appeared worthwhile to ascertain the transcortin capacity in several clinical states. Data are presented in this paper on the transcortin binding capacity in the plasma of newborn infants and their mothers; in normal children of various ages; in patients with cirrhosis of the liver; in patients with miscellaneous diseases; and following the administration of estrogenic substances.

\section{METHODS AND MATERIALS}

Maternal and fetal blood was taken into heparinized syringes immediately following delivery from the antecubital vein and the umbilical vein of the placenta, respectively. The plasma was separated from the erythro-

* This investigation has been supported in part by a grant (A-1240) from the National Institute of Arthritis and Metabolic Diseases of the National Institutes of Health, United States Public Health Service. cytes shortly following withdrawal of the blood. Some of the plasma was stored at $-10^{\circ} \mathrm{C}$. The determination of the binding capacity of transcortin was performed and calculated according to methods previously described $(1,5)$. Unless otherwise indicated, all binding experiments were performed by dialyzing $10 \mathrm{ml}$. of diluted plasma (1:5 with physiological saline) against $30 \mathrm{ml}$. of saline containing approximately $0.3 \mu \mathrm{g}$. of $\mathrm{C}^{14}$-cortisol. The binding was determined with and without the addition of $1 \mu \mathrm{g}$. of cortisol to the saline in order to measure the decrease in the binding caused by the addition of the carrier cortisol. In a previously published paper (5) we demonstrated that under the conditions of our assay the binding of cortisol by plasma was essentially due to transcortin and not to other plasma proteins. Hence, the term "transcortin binding of $\mathrm{C}^{\mathbf{1 4}}$-cortisol" will refer to the percentage of $\mathrm{C}^{\mathbf{1 4}}$-cortisol bound by $10 \mathrm{ml}$. of diluted plasma, and the term "transcortin capacity" will be used to indicate the decrease in binding caused by the addition of $1 \mu \mathrm{g}$. of cortisol in the dialysis conditions outlined above. It should be pointed out that the "binding capacity" will be inversely related to the decrease in the binding caused by the addition of $1 \mu \mathrm{g}$. of cortisol, i.e., the less the decrease in the binding, the higher the binding capacity, and vice versa.

Some of the shortcomings of the method used were

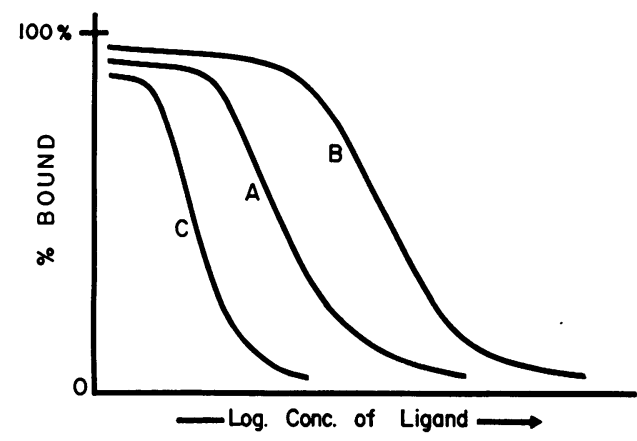

Fig. 1. Representative Theoretical Curves for the

Binding of Cortisol (Ligand) by Transcortin

Curve $A$ is assumed to portray conditions under normal concentrations of plasma transcortin; Curve B under increased transcortin levels; and Curve $C$ under decreased transcortin concentration. It is to be noted that with each individual curve the concentration of transcortin is constant, whereas that of cortisol is shown to increase. 
TABLE I

Transcortin binding of $C^{14}$-cortisol and capacity in the plasmas of mothers and their newborn infants*

\begin{tabular}{cccccc}
\hline & \multicolumn{2}{c}{ Mothers } & & \multicolumn{2}{c}{$\begin{array}{c}\text { Newborn infants } \\
\text { (cord blood) }\end{array}$} \\
\cline { 2 - 3 } \cline { 5 - 6 } Subject & $\begin{array}{c}\text { \%of C14 } \\
\text { cortisol } \\
\text { bound }\end{array}$ & $\begin{array}{c}\text { Binding } \\
\text { capacity }\end{array}$ & & $\begin{array}{c}\text { \% of C14 } \\
\text { cortisol } \\
\text { bound }\end{array}$ & $\begin{array}{c}\text { Binding } \\
\text { capacity }\end{array}$ \\
\hline Sc. & 92 & 14 & & 45 & 1 \\
Cu. & 92 & 11 & & 63 & 7 \\
Ja. & 87 & 14 & & 74 & 22 \\
Ko. & 91 & 13 & & 66 & 20 \\
Fo. & 92 & 11 & & 72 & 17 \\
Ma. & 87 & 11 & & 65 & 19 \\
Ki. & 94 & 11 & & 66 & 32 \\
Pe. & 79 & 13 & & 57 & 24 \\
Am. & 90 & 7 & & 58 & 14 \\
Ra. & 91 & 8 & & 66 & \\
Ru. & 90 & 11 & & 61 & 14 \\
Sl. & 86 & 7 & 72 & 16 \\
We. & 86 & 8 & & 75 & 21 \\
Hu. & 89 & 10 & 66 & 17 \\
Su. & 90 & 11 & 64 & 22 \\
Ca. & & & 66 & \\
Ba. & 80 & 9 & 55 & 18 \\
Ch. & 79 & 7 & 66 & 9 \\
Sa. & 87 & 9 & 58 & \\
& & & & &
\end{tabular}

Means \pm S. D. $\quad 88 \pm 4.6 \quad 10 \pm 2.3$

$64 \pm 7.2 \quad 17 \pm 7.3$

* The binding of $0.3 \mu \mathrm{g}$. of $\mathrm{C}^{14}$-cortisol and the change, shown as the binding capacity, upon the addition of $1.0 \mu \mathrm{g}$. of cortisol; dialysis of plasma diluted 1:5 with saline against saline.

t It should be noted in this and in the following tables, that the binding capacity is inversely related to the values given in the column.

discussed previously, but it would appear that this offers, at present, the best approach to the measurement of transcortin capacity (5). The major shortcoming of the method is the inability to measure the actual concentration of transcortin in the plasma. Nevertheless, knowing three values (the initial binding of $\mathrm{C}^{\mathbf{1 4}}$-cortisol, the binding capacity, and the endogenous cortisol concentration), one can locate reliably the point on one of the binding curves (Figure 1) at which a particular experiment was performed. Since the determination of endogenous cortisol concentrations is impractical, we have relied on 17hydroxycorticosteroid concentrations (17-OHCS) as approximations of cortisol levels, taking the values either from the literature or from our own data.

The radioactivity in the samples and the plasma 17OHCS were determined by methods previously described $(7,8)$. The electrophoretic pattern of the plasma proteins was determined in a Perkin-Elmer Model 38 electrophoresis apparatus. All samples were dialyzed to equilibrium in phosphate buffer, $\mathrm{pH} 8.6(0.1 \mathrm{M})$, and the electrophoretic determinations were made according to standard techniques.

\section{RESULTS}

The plasma of 10 normal adult males and females (18 to 45 years of age) bound $84 \pm 12.4$ per cent (S.D.) of the $\mathrm{C}^{14}$-cortisol and showed a decrease in the binding upon the addition of $1 \mu \mathrm{g}$. of cortisol of $26 \pm 7.6$ per cent.

\section{Binding capacity in newborn infants and their mothers and in children}

In Table I are shown the values for transcortin binding of $\mathrm{C}^{14}$-cortisol and capacity of mothers and their newborn infants. The binding of $\mathrm{C}^{14}$ cortisol exhibited by the mothers' plasmas was higher ( $88 \pm 4.6$ per cent) than that shown by the newborn infants' plasmas ( $64 \pm 7.2$ per cent). The differences using the method of paired variates were statistically significant $(p<0.01)$. The binding by the plasmas of newborn infants represents the lowest mean value we have observed. The addition of $1 \mu \mathrm{g}$. of cortisol resulted in a greater drop of bound cortisol in the plasma of infants $(17 \pm 7.3$ per cent $)$ than of their mothers $(10 \pm 2.3$ per cent), indicating a lower ( $\mathrm{p}<$ 0.01 ) binding capacity for cortisol in the former.

The determination of the transcortin levels in the plasma of children of various ages revealed

TABLE II

Transcortin binding of $C^{14}$-cortisol and capacity in the plasmas of children

\begin{tabular}{|c|c|c|c|}
\hline Subject & Age & $\begin{array}{c}\% \text { of } \mathrm{C}^{14}- \\
\text { cortisol } \\
\text { bound }\end{array}$ & $\begin{array}{c}\text { Binding } \\
\text { capacity }\end{array}$ \\
\hline $\begin{array}{l}\text { P. P.** } \\
\text { P. P.* } \\
\text { P. P.* } \\
\text { P. P.* } \\
\text { P. P.* } \\
\text { W. D. } \\
\text { P. P.* } \\
\text { P. P.* } \\
\text { K. B. } \\
\text { K. F. } \\
\text { C. N. } \\
\text { P. P.* } \\
\text { H. R. } \\
\text { P. P.* } \\
\text { C. R. } \\
\text { P. P.* } \\
\text { P. P.* } \\
\text { P. M. } \\
\text { P. P.* } \\
\text { K. Mc. } \\
\text { J. B. } \\
\text { S. A. } \\
\text { S. W. } \\
\text { R. D. } \\
\text { J. T. } \\
\text { D. B. }\end{array}$ & $\begin{array}{c}\text { 15-3 mos. } \\
2-3 \text { mos. } \\
2-4 \text { mos. } \\
1-4 \text { mos. } \\
3-4 \text { mos. } \\
4 \text { mos. } \\
5 \text { mos. } \\
9-11 \text { mos. } \\
12 / 12 \text { yrs. } \\
1 \text { 5/12 yrs. } \\
110 / 12 \text { yrs. } \\
1 \text { 6/12-2 yrs. } \\
36 / 12 \text { yrs. } \\
42 / 12-5 \text { yrs. } \\
55 \text { yrs. } \\
5 \text { yrs. } \\
3-6 \text { yrs. } \\
6 \text { yrs. } \\
4-7 \text { 6/12 yrs. } \\
8 \text { yrs. } \\
86 / 12 \text { yrs. } \\
9 \text { yrs. } \\
9 \text { yrs. } \\
96 / 12 \text { yrs. } \\
115 / 12 \text { yrs. } \\
1110 / 12 \text { yrs. }\end{array}$ & $\begin{array}{l}95 \\
91 \\
93 \\
90 \\
88 \\
92 \\
93 \\
96 \\
96 \\
98 \\
91 \\
98 \\
96 \\
96 \\
95 \\
98 \\
92 \\
97 \\
96 \\
96 \\
93 \\
93 \\
94 \\
94 \\
97 \\
97\end{array}$ & $\begin{array}{l}28 \\
22 \\
23 \\
26 \\
29 \\
30 \\
28 \\
17 \\
21 \\
\\
\\
18 \\
21 \\
22 \\
\\
24 \\
18 \\
24 \\
22 \\
22 \\
\\
28 \\
24 \\
22 \\
\\
21\end{array}$ \\
\hline Means $\pm S$. D. & & $94 \pm 2.7$ & $23 \pm 3.7$ \\
\hline
\end{tabular}

* Pooled plasma. 
TABLE III

Changes in transcortin binding of $C^{14}$-cortisol and capacity during estrogen administration

\begin{tabular}{|c|c|c|c|c|c|c|}
\hline $\begin{array}{l}\text { Subject, } \\
\text { diagnosis }\end{array}$ & $\begin{array}{l}\text { Sex, } \\
\text { age }\end{array}$ & Therapy & $\begin{array}{c}\text { Days } \\
\text { following } \\
\text { beginning } \\
\text { of therapy }\end{array}$ & $\begin{array}{l}\text { C14-cortisol } \\
\text { bound }\end{array}$ & $\begin{array}{l}\text { Binding } \\
\text { capacity }\end{array}$ & $\begin{array}{c}\text { Plasma } \\
17-\mathrm{OHCS}\end{array}$ \\
\hline $\begin{array}{l}\text { E. M. } \\
\text { Carcinoma of breast }\end{array}$ & $\begin{array}{l}F \\
49\end{array}$ & $\begin{array}{l}\text { Stilbestrol } \\
5 \mathrm{mg} \text {. } \\
3 \times \text { daily }\end{array}$ & $\begin{array}{r}0 \\
13 \\
20 \\
40\end{array}$ & $\begin{array}{l}\% \\
96 \\
98 \\
98 \\
99\end{array}$ & $\begin{array}{r}29 \\
10 \\
10 \\
6\end{array}$ & $\begin{array}{c}\mu g . \% \\
14 \\
54 \\
69 \\
60\end{array}$ \\
\hline $\begin{array}{l}\text { N. A. } \\
\text { Carcinoma of breast }\end{array}$ & $\begin{array}{l}F \\
52\end{array}$ & $\begin{array}{l}\text { Stilbestrol } \\
5 \mathrm{mg} \text {. } \\
3 \times \text { daily }\end{array}$ & $\begin{array}{r}0 \\
17 \\
26\end{array}$ & $\begin{array}{l}85 \\
96 \\
98\end{array}$ & $\begin{array}{r}24 \\
12 \\
9\end{array}$ & $\begin{array}{l}23 \\
70 \\
66\end{array}$ \\
\hline $\begin{array}{l}\text { R. } U_{\text {. }} \\
\text { Carcinoma of prostate }\end{array}$ & $\begin{array}{l}M \\
60\end{array}$ & $\begin{array}{l}\text { Stilbestrol } \\
5 \mathrm{mg} \text {. } \\
3 \times \text { daily }\end{array}$ & $\begin{array}{r}0 \\
0 \\
4 \\
7 \\
10 \\
16\end{array}$ & $\begin{array}{l}86 \\
76 \\
98 \\
98 \\
98 \\
98\end{array}$ & $\begin{array}{l}27 \\
26 \\
17 \\
12 \\
12 \\
10\end{array}$ & $\begin{array}{l}16 \\
20 \\
48 \\
36 \\
39 \\
40\end{array}$ \\
\hline $\begin{array}{l}\text { H. S. } \\
\text { Carcinoma of prostate }\end{array}$ & $\begin{array}{l}M \\
62\end{array}$ & $\begin{array}{l}\text { Stilbestrol } \\
1 \mathrm{mg} . \\
3 \times \text { daily }\end{array}$ & $\begin{array}{r}0 \\
0 \\
2 \\
9 \\
15 \\
21\end{array}$ & $\begin{array}{l}90 \\
87 \\
98 \\
98 \\
99 \\
99\end{array}$ & $\begin{array}{l}25 \\
23 \\
20 \\
16 \\
13 \\
11\end{array}$ & $\begin{array}{l}10 \\
14 \\
24 \\
31 \\
38 \\
34\end{array}$ \\
\hline $\begin{array}{l}\text { S. W. } \\
\text { Myocardial infarction }\end{array}$ & $\begin{array}{l}\mathrm{M} \\
72\end{array}$ & $\begin{array}{l}\text { Ethinyl } \\
\text { estradiol } \\
0.5 \mathrm{mg} \text {. daily }\end{array}$ & $\begin{array}{r}0 \\
13\end{array}$ & $\begin{array}{l}91 \\
96\end{array}$ & $\begin{array}{l}21 \\
12\end{array}$ & $\begin{array}{l}14 \\
53\end{array}$ \\
\hline $\begin{array}{l}\text { F. M. } \\
\text { Carcinoma of breast }\end{array}$ & $\begin{array}{l}\mathrm{F} \\
70\end{array}$ & $\begin{array}{l}\text { Stilbestrol } \\
5 \mathrm{mg} \text {. } \\
3 \times \text { daily }\end{array}$ & $\begin{array}{r}0 \\
34\end{array}$ & $\begin{array}{l}90 \\
98\end{array}$ & $\begin{array}{l}23 \\
11\end{array}$ & $\begin{array}{l}13 \\
63\end{array}$ \\
\hline $\begin{array}{l}\text { M. M. } \\
\text { Carcinoma of breast }\end{array}$ & $\begin{array}{l}\mathrm{F} \\
67\end{array}$ & $\begin{array}{l}\text { Stilbestrol } \\
5 \mathrm{mg} \text {. } \\
3 \times \text { daily }\end{array}$ & $\begin{array}{r}0 \\
29\end{array}$ & $\begin{array}{l}95 \\
98\end{array}$ & $\begin{array}{r}24 \\
7\end{array}$ & $\begin{array}{l}15 \\
48\end{array}$ \\
\hline $\begin{array}{l}\text { M.S. } \\
\text { Carcinoma of breast }\end{array}$ & $\begin{array}{l}\mathrm{F} \\
57\end{array}$ & $\begin{array}{l}\text { Stilbestrol } \\
5 \mathrm{mg} \text {. } \\
3 \times \text { daily }\end{array}$ & $\begin{array}{r}0 \\
29\end{array}$ & $\begin{array}{l}96 \\
99\end{array}$ & $\begin{array}{l}20 \\
10\end{array}$ & $\begin{array}{l}18 \\
44\end{array}$ \\
\hline
\end{tabular}

significantly $(\mathrm{p}<0.05)$ higher binding of $\mathrm{C}^{14}$ cortisol (94 \pm 2.7 per cent) than in normal adults. The transcortin capacity ( $23 \pm 3.7$ per cent) fell within the normal range for adults. The ages of the children ranged from six weeks to nearly 12 years. In many cases it was necessary to pool the plasmas of several children. No significant difference was observed in the transcortin binding of $\mathrm{C}^{14}$-cortisol and capacity among the various age groups studied (Table II). Unfortunately, we do not have data on transcortin levels in the age group of 12 to 18 years.

\section{Effects of estrogen administration on the bind- ing capacity}

In previously published work we demonstrated increased transcortin binding of $\mathrm{C}^{14}$-cortisol and capacity during pregnancy, especially the last trimester (5). To ascertain whether these increased transcortin levels might in some measure be due to the increased circulating levels of estrogens, several subjects were given stilbestrol or ethinyl estradiol and the plasma transcortin levels and the 17-OHCS were measured. The data are shown in Table II. It is readily apparent that the administration of the estrogen caused an increase in the transcortin binding of $\mathrm{C}^{14}$-cortisol and, especially, in the transcortin capacity, resulting in the highest values we have observed in our laboratory. It is of interest to note that the transcortin levels increased with time during administration of the drugs. It should be pointed out that the binding capacity is of greater value in evaluating the effect of estrogens on transcortin, since the 
transcortin binding of $\mathrm{C}^{14}$-cortisol approached 100 per cent in all the subjects given estrogens and even great variations could not be measured with the presently employed method. On the other hand, the transcortin capacity would reflect more accurately the effects of the estrogen. The plasma 17-OHCS levels rose concomitant with the changes in the binding. The problem as to which occurs first, the rise in the $17-\mathrm{OHCS}$ or transcortin, is now being further investigated.

\section{Binding capacity in conditions associated with plasma protein abnormalities}

The results in a group of patients with cirrhosis of the liver are shown in Table IV. All the subjects studied were male, except for Patient Ko. ( 40 year female), and the ages ranged from 32 to 60 years. In general, the transcortin binding of $\mathrm{C}^{14}$-cortisol and capacity were not significantly different $(0.3<p<0.4)$ from those observed in normal subjects. There appeared to be no correlation between the transcortin levels and the clinical or laboratory findings. In Table $\mathrm{V}$ are shown the data obtained in six patients with multiple myeloma. As a group, the transcortin binding of $\mathrm{C}^{14}$-cortisol and capacity of the plasma of these subjects did not differ materially from those seen in normal subjects. There was no apparent correlation between the plasma protein changes and the transcortin levels. In Table VI are shown

TABLE IV

Transcortin binding of $\mathrm{C}^{14}$-cortisol and capacity in patients with cirrhosis of the liver

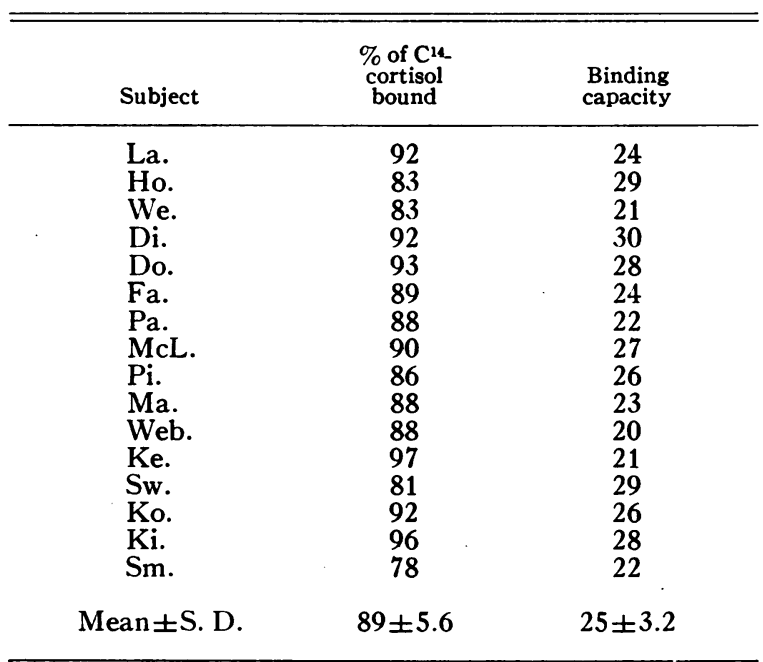

TABLE V

Transcortin binding of $\mathrm{C}^{14}$-cortisol and capacity in patients with multiple myeloma

\begin{tabular}{lcccccccc}
\hline & $\begin{array}{c}\text { \% of C14. } \\
\text { cortisol } \\
\text { bound }\end{array}$ & $\begin{array}{c}\text { Binding } \\
\text { capacity }\end{array}$ & & \multicolumn{4}{c}{$\begin{array}{c}\text { Plasma protein } \\
\text { (\% of total) }\end{array}$} \\
\cline { 5 - 10 } & Alb. & $\alpha_{1}$ & $\alpha_{2}$ & $\beta$ & $\gamma$ \\
\hline Go. & 79 & 32 & 27 & 7 & 13 & 17 & 35 \\
De. & 69 & 28 & 14 & 5 & 16 & 13 & 51 \\
To. & 85 & 28 & 16 & 10 & 8 & 13 & 52 \\
Pr. & 88 & 23 & 23 & 3 & 8 & 15 & 51 \\
S1. & 83 & 26 & 41 & 14 & 10 & 9 & 26 \\
Sa. & 88 & 30 & 18 & 2 & 3 & 11 & 66
\end{tabular}

Mean \pm S. D. $82 \pm 7.2 \quad 28 \pm 3.1$

the transcortin levels in three children with the nephrotic syndrome and in four patients with active rheumatoid arthritis. The children with the nephrotic syndrome had hypoalbuminemia, hypercholesteremia and generalized edema. The transcortin levels are somewhat lower than those observed for normal children of similar age group, but more cases will have to be studied before definite conclusions regarding the transcortin levels in nephrosis can be reached. The transcortin binding of $\mathrm{C}^{14}$-cortisol by the plasmas of the four adult patients with rheumatoid arthritis are somewhat higher than that observed in normal adult subjects, but the binding capacity was within normal limits.

\section{Binding of conjugated metabolites of $C^{\mathbf{1 4}_{-}}$ cortisol}

Experiments were performed to ascertain the binding of the conjugated metabolites of cortisol

TABLE VI

Transcortin binding of $C^{\mathbf{1 4}}$-cortisol and capacity in patients with nephrosis and in patients with rheumatoid arthritis

\begin{tabular}{lccccc}
\hline Subject & Diagnosis & Age, sex & $\begin{array}{c}\text { \% of C14 } \\
\text { cortisol } \\
\text { bound }\end{array}$ & $\begin{array}{c}\text { Binding } \\
\text { capacity }\end{array}$ \\
\hline & & yrs. & & & \\
D. M. & Nephrosis & 9 & M & 81 & 27 \\
J. L. & Nephrosis & $3 \frac{1}{2}$ & M & 89 & 25 \\
M. R. & Nephrosis & 9 & M & 71 & 19 \\
W. N. & $\begin{array}{c}\text { Rheumatoid } \\
\text { arthritis }\end{array}$ & 36 & M & 93 & 29 \\
A. B. & $\begin{array}{c}\text { Rheumatoid } \\
\text { arthritis }\end{array}$ & 65 & F & 96 & 24 \\
E. F. & $\begin{array}{c}\text { Rheumatoid } \\
\text { arthritis }\end{array}$ & 52 & F & 91 & 26 \\
M. H. & $\begin{array}{c}\text { Rheumatoid } \\
\text { arthritis }\end{array}$ & 24 & F & 92 & 22 \\
& & & & &
\end{tabular}


by transcortin, since these conjugates might encroach on the ability of transcortin to bind cortisol. Following the injection of $\mathrm{C}^{14}$-cortisol into a normal male subject, the urine obtained during the initial two hours following the administration of the $\mathrm{C}^{14}$-cortisol was used as a source of conjugated metabolites of $\mathrm{C}^{14}$-cortisol. One $\mathrm{ml}$. of the urine, containing approximately $10,000 \mathrm{cpm}$, was added either to 5 per cent human serum albumin (HSA) or to saline and dialyzed against undiluted plasma. Dialysis was performed for eight days, since preliminary observations indicated that equilibrium was not established between the plasma and the HSA when dialyzed for three days, but did occur in eight days. The binding of urinary $\mathrm{C}^{14}$-cortisol metabolites by the plasma was 1 per cent when the plasma was dialyzed against albumin. It appears, therefore, that there is no special protein which binds the conjugated metabolites of cortisol, comparable to that which binds cortisol. The binding exhibited by the plasma ( 54 to 59 per cent) dialyzed against the urinary metabolites of cortisol was similar to that found with HSA (9).

Since the amount of cortisol and other steroid metabolites present in the urine sample added to the dialysis system was calculated to be at least $10 \mu \mathrm{g}$., and since this amount of steroid metabolites may exceed the binding capacity of the plasma transcortin in the $10 \mathrm{ml}$. of plasma, the following experiments were performed. Dialysis of diluted (1:5) plasma was performed against saline to which $0.3 \mu \mathrm{g}$. of $\mathrm{C}^{14}$-cortisol was added. In addition, in another series, $1 \mathrm{ml}$. of urine from a normal male subject was added to the saline in order to establish the competition of the nonradioactive steroid metabolites of cortisol (and other steroids) with the $\mathrm{C}^{14}$-cortisol for transcortin. In a third experiment some of the urine was extracted with ether, boiled, cooled, then added to the saline, in order to exclude any unconjugated metabolites. Again, the urines used were calculated to contain a minimum of $10 \mu \mathrm{g}$. of cortisol metabolites. When no urine was present, 94 per cent of the $\mathrm{C}^{14}$-cortisol was bound by the plasma; when etherextracted urine was added 84 per cent was bound; and with an original urine 80 per cent was bound. The findings indicate that large amounts of conjugated metabolites of cortisol (and of other steroids) in the urine, and, by inference, in plasma, do not compete significantly with the binding of cortisol by transcortin.

\section{DISCUSSION}

For a fuller interpretation and understanding of the results presented it may be worthwhile to consider some of the aspects of the binding of a ligand (cortisol) by a protein (transcortin). As shown in Figure 1 the plotting of the percentage of binding against the concentration of cortisol in the presence of a normal amount of transcortin (Curve A) results in the appearance of a sigmoid curve. The two extremities of this curve approach a plateau, indicating that at very low or very high concentrations of cortisol very little change in the percentage of bound cortisol (transcortin capacity) occurs. It is apparent that under the conditions of our experiments, the binding of $\mathrm{C}^{14}$-cortisol occurs somewhere on the descending part of Curve A as evidenced by the greatly decreased binding induced by the addition of $1 \mu \mathrm{g}$. of cortisol. Curve $B$ represents the results that prevail when the concentration of transcortin is increased in the plasma. Not only will the percentage of bound cortisol be increased somewhat over that in Curve A, but, more importantly, the transcortin capacity is greatly increased so that $1 \mu \mathrm{g}$. of cortisol produces a smaller drop in the percentage of bound cortisol. Curve $\mathrm{B}$ approximates the conditions present in pregnancy or following the administration of estrogens. Curve $\mathrm{C}$ depicts the conditions when the transcortin concentration is decreased. Under these circumstances, the binding of cortisol, even at normal plasma levels of this steroid, will be greatly reduced and the decrease in the binding induced by extra cortisol will be smaller than that in Curves A or B. Conditions similar to those shown in Curve $C$ are thought to prevail in newborn infants. Since under normal circumstances the plasma concentration of transcortin is small, the lower plateau is approached quickly. As the concentration of cortisol not bound by transcortin increases, its association with the large reservoir of albumin in the plasma becomes of increasing importance.

In previously published work it was shown that the transcortin binding of $\mathrm{C}^{14}$-cortisol and capacity are increased during pregnancy, especially in the last trimester (5), findings compatible with 
increased plasma transcortin levels (see Figure 1). Since there is a definite increase in the plasma cortisol during that period of pregnancy, without classical signs of hypercorticism, we advanced the hypothesis that transcortin-bound cortisol was biologically inactive and that the concentration of cortisol in the plasma would have to exceed the effective capacity of transcortin before physiological, and especially pharmacological, effects of cortisol became evident. In the present study the transcortin binding of $\mathrm{C}^{14}$-cortisol in the plasma of the mothers immediately post partum was 88 per cent on the average as compared to 96 per cent obtained during the last trimester. This difference is best explained by the substantial rises in the cortisol levels in women in labor $(10,11)$ with resultant encroachment on the capacity to bind the added $\mathrm{C}^{14}$-cortisol (see Curve B in Figure 1). Nevertheless, the binding capacity, as shown by the decrease induced by the addition of $1 \mu \mathrm{g}$. of cortisol, remained high, especially when compared to that of normal subjects.

From the foregoing discussion it appears that patients with increased levels of plasma transcortin should metabolize $\mathrm{C}^{14}$-cortisol slower than normal subjects. Decreased rates of metabolism of $\mathrm{C}^{14}$ cortisol have been shown to occur in pregnant women $(12,13)$. It should be emphasized, however, that transcortin may be only one of the factors influencing rates of cortisol metabolism and that the other factors (state of liver function, metabolic rate and so forth) probably play important roles. This is illustrated by the transcortin binding of $\mathrm{C}^{14}$-cortisol and capacity in newborn infants. Even though the plasma 17-OHCS are much lower in the plasma of the newborns (cord blood) immediately post partum than in the plasma of the mothers $(10,11,14)$, but on the average similar to those of normal adults, the transcortin binding of $\mathrm{C}^{14}$-cortisol was the lowest observed by us thus far (see Curve C in Figure 1). Since it has been shown that the plasma $17-\mathrm{OHCS}$ decrease to extremely low levels in newborn infants within 24 hours following birth (14), it will be interesting to ascertain the transcortin levels during the first few weeks of life. Upon the addition of $1 \mu \mathrm{g}$. of cortisol the binding decreased to very low levels in the newborn infants (mean, 47 per cent, compared to 78 per cent in the mothers, 58 per cent in normal subjects and 83 per cent in the third trimester of pregnancy). Since it has been shown that the concentration of albumin in the plasma of newborn infants is equal to that present in the plasma of children or adults (15), the binding of $\mathrm{C}^{14}$-cortisol exhibited by the plasma of newborn infants, following the addition of $1 \mu \mathrm{g}$. of cortisol, can be ascribed to its content of albumin (1). In spite of lower transcortin binding of $\mathrm{C}^{14}$ cortisol, newborn infants have been shown to metabolize cortisol at a slower rate than older children $(16,17)$. It is possible that the liver is implicated in the slower metabolism of cortisol in the newborn infant.

The transcortin binding of $\mathrm{C}^{14}$-cortisol in children, exclusive of the newborn infants, was somewhat higher than in adult subjects. It is possible that the increased binding shown by the older children's plasma may be due to slightly lower circulating levels of cortisol as inferred from the plasma 17-OHCS concentration (18) and may also explain the normal (23 per cent) drop in the binding upon the addition of $1 \mu \mathrm{g}$. of cortisol. Again, for a fuller understanding of the last statement it may be worthwhile to refer to Curve $A$ in Figure 1. It is apparent that the binding of the $\mathrm{C}^{14}$-cortisol by transcortin will be greatly dependent on the concentration of endogenous cortisol in the plasma. At high concentrations of cortisol the binding will be lower down on the curve and the reverse is true for low cortisol levels. Whether the cortisol levels are high or low, but still within the normal range, the binding capacity will be of approximately the same order of magnitude since the initial point of the binding in both cases will be usually located on the upper half of the sloping curve.

Of great interest was the increased transcortin binding of $\mathrm{C}^{14}$-cortisol capacity brought about by the administration of estrogens. We interpret our data to indicate that the drug caused a sharp increase in the concentration of transcortin. This probably explains, in large measure, the ability of subjects given estrogens to tolerate very high levels of cortisol $(13,19)$. It will be interesting to establish which occurs first, the rise in plasma transcortin or the 17-OHCS concentration. Since it has been shown that the total amounts of corticosteroids produced and excreted in the urine by patients receiving estrogens and in pregnant women are normal or reduced $(13,20,21)$, con- 
comitant with high plasma $17-\mathrm{OHCS}$, it can be predicted that the effect of the estrogens or pregnancy is to increase the plasma transcortin levels before the 17-OHCS rise. The increased amounts of transcortin would bind more cortisol and the $17-\mathrm{OHCS}$ in the plasma would rise, due to the unavailability for metabolism of the transcortinbound steroid. The increased transcortin binding of $\mathrm{C}^{14}$-cortisol capacity in pregnancy may possibly be due to the increased levels of circulating estrogens. The binding capacity increased with time during the administration of the estrogens.

Since the possibility exists that the increased amounts of transcortin induced by estrogen administration originate in the liver, a group of patients with cirrhosis of the liver was examined for transcortin binding of $\mathrm{C}^{14}$-cortisol and capacity. Both were found essentially normal. Two explanations may be advanced for this finding. It is possible that a cirrhotic liver would synthesize lesser amounts of transcortin were it not for the stimulating effect of the increased circulating levels of the estrogens probably present in this condition. The other possible explanation merely states that the liver is not the site of transcortin synthesis. It was with this possibility in mind that several conditions associated with abnormal protein metabolism (multiple myeloma, rheumatoid arthritis, nephrosis) were investigated regarding the transcortin binding of $\mathrm{C}^{\mathbf{1 4}}$-cortisol and capacity in the plasma of these patients. Even though some changes from the normal were seen in the patients, especially those with nephrosis and rheumatoid arthritis and in a few patients with multiple myeloma, in general, the transcortin levels were not greatly divergent from those of normal subjects. Daughaday (22) has published the corticosteroidbinding capacity of a relatively small number of patients and has shown it to be decreased in two patients with portal cirrhosis and in one with acute hepatic necrosis. One subject with nephrosis and another with multiple myeloma also had decreased binding capacity. Even though an occasional patient with the above diseases in our studies showed decreased transcortin binding of $\mathrm{C}^{14}$-cortisol and capacity, larger series of these patients will have to be examined before more definite conclusions can be reached regarding the transcortin levels. Special attention must be devoted to nephrosis, since the $\alpha_{1}$-globulin levels tend to be low in pa- tients with the syndrome and transcortin is thought to be an $\alpha_{1}$-globulin $(2,5)$.

It would appear from the results presented that the various conjugated metabolites of cortisol and other steroids in the urine are not bound by transcortin to any significant extent. Hence, in all probability, the conjugated metabolites in the blood do not interfere with the binding of cortisol.

\section{SUMMARY}

1. The plasma transcortin binding of $\mathrm{C}^{\mathbf{1 4}}$ cortisol and capacity, when compared with those of normal adults, are low in newborn infants, possibly increased in children, normal in subjects with cirrhosis of the liver, probably reduced in subjects with the nephrotic syndrome and in some patients with multiple myeloma and slightly increased in subjects with rheumatoid arthritis.

2. The administration of estrogens causes greatly increased transcortin binding of $\mathrm{C}^{\mathbf{1 4}}$-cortisol and capacity in the plasma concomitant with greatly increased levels of the 17-OHCS. Effects of hypercorticism are probably prevented in these subjects by the transcortin binding of cortisol, which is thought to render cortisol biologically inactive and not available for metabolism.

3. The conjugated metabolites of cortisol and other steroids were not bound significantly by transcortin.

\section{ACKNOWLEDGMENTS}

We wish to acknowledge the cooperation of Dr. Robert Patterson of the Medical Foundation, Buffalo, N. Y., who supplied us with many of the plasmas from mothers and newborn infants; Dr. P. Calcagno for plasmas from nephrotic and normal children; Dr. M. Grumbach for plasmas from children; and Dr. A. Carter for some of the plasmas in patients receiving estrogens. $\mathrm{C}^{\mathbf{1 4}}$-cortisol was generously supplied by the Endocrinology Study Section of the National Institutes of Health.

Valuable technical assistance was supplied by Mrs. Jean Valvo, Mr. Elek Karsay and Mr. Lawrence Beecher. We wish to thank Dr. D. Woernley for performing the electrophoretic analyses of the plasma proteins.

\section{REFERENCES}

1. Sandberg, A. A., Slaunwhite, W. R., Jr., and Antoniades, $H$. N. The binding of steroids and steroid conjugates to human plasma proteins. Rec. Progr. Hormone Res. 1957, 13, 209.

2. Daughaday, W. H. Binding of corticosteroids by plasma proteins. IV. The electrophoretic demonstration of corticosteroid binding globulin. J. clin. Invest. 1958, 37, 519. 
3. Bush, I. E. The physicochemical state of cortisol in blood in Ciba Foundation Colloquia on Endocrinology, vol. 11. Boston, Little, Brown and Co., 1957, p. 263.

4. Upton, G. V., and Bondy, P. K. The binding of cortisol by plasma protein. Arch. Biochem. 1958, 78, 197.

5. Slaunwhite, W. R., Jr., and Sandberg, A. A. Transcortin: A corticosteroid-binding protein of plasma. J. clin. Invest. 1959, 38, 384.

6. Daughaday, W. H. Binding of corticosteroids by plasma proteins. III. The binding of corticosteroid and related hormones by human plasma and plasma protein fractions as measured by equilibrium dialysis. J. clin. Invest. 1958, 37, 511.

7. Sandberg, A. A., and Slaunwhite, W. R., Jr. Studies on phenolic steroids in human subjects. II. The metabolic fate and hepato-biliary-enteric circulation of $\mathrm{C}^{14}$-estrone and $\mathrm{C}^{14}$-estradiol in women. $\mathrm{J}$. clin. Invest. 1957, 36, 1266.

8. Peterson, R. E., Karrer, A., and Guerra, S. L. Evaluation of the Silber-Porter procedure for determination of plasma hydrocortisone. Analyt. Chem. 1957, 29, 144.

9. Slaunwhite, W. R., Jr., and Sandberg, A. A. The binding of urinary conjugated steroids to serum albumin: A new method of extraction. Endocrinology 1958, 62, 283.

10. Gemzell, C. A. Variations in plasma levels of $17-$ hydroxycorticosteroids in mother and infant following parturition. Acta endocr. (Kbh.) 1954, 17, 100.

11. Migeon, C. J., Prystowsky, H., Grumbach, M. M., and Byron, M. C. Placental passage of 17-hydroxycorticosteroids: Comparison of the levels in maternal and fetal plasma and effect of ACTH and hydrocortisone administration. J. clin. Invest. 1956, 35, 488.

12. Migeon, C. J., Bertrand, J., and Wall, P. E. Physiological disposition of 4-C ${ }^{14}$-cortisol during late pregnancy. J. clin. Invest. 1957, 36, 1350.
13. Cohen, M., Stiefel, M., Reddy, W. J., and Laidlaw, J. C. The secretion and disposition of cortisol during pregnancy. J. clin. Endocr. 1958, 18, 1076.

14. Klein, R., Fortunato, J., and Papadatos, C. Free blood corticoids in the newborn infant. J. clin. Invest. 1954, 33, 35.

15. Oberman, J. W., Gregory, K. O., Burke, F. G., Ross, S., and Rice, E. C. Electrophoretic analysis of serum proteins in infants and children. I. Normal values from birth to adolescence. New Engl. J. Med. 1956, 255, 743.

16. Bongiovanni, A. M., Eberlein, W. R., Westphal, M., and Boggs, T. Prolonged turnover rate of hydrocortisone in the newborn infant. J. clin. Endocr. 1958, 18, 1127.

17. Grumbach, M. M., Ducharme, J. R., and Morishima, A. On the metabolism of hydrocortisone and its metabolites in premature and newborn infants. Proc. Soc. Pediat. Res. (Buck Hill Falls, Pa.) May, 1959.

18. Ely, R. S., Kelley, V. C., and Raile, R. B. Studies of 17-hydroxycorticosteroids in children. I. Peripheral blood levels in health and disease. J. Pediat. 1953, 42, 38.

19. Wallace, E. Z., Silverberg, H. I., and Carter, A. C. Effect of ethinyl estradiol of plasma 17-hydroxycorticosteroids, ACTH responsiveness and hydrocortisone clearance in man. Proc. Soc. exp. Biol. (N. Y.) 1957, 95, 805.

20. Peterson, R. E. The miscible pool and turn-over rate of corticosteroids. Rec. Progr. Hormone Res. In press.

21. Martin, J. D., and Mills, I. H. The effect of pregnancy on adrenal steroid metabolism. Clin. Sci. 1958, 17, 137.

22. Daughaday, W. H. Binding of corticosteroids by plasma proteins. V. Corticosteroid-binding globulin activity in normal human beings and in certain disease states. Arch. intern. Med. 1958, 101, 286. 